\title{
Diel Changes in Habitat Use by Two Tidepool Fishes
}

\author{
Jana L. D. Davis
}

\begin{abstract}
I examined the effects of low-tide timing on tidepool use by two southern California fishes, Clinocottus analis and Girella nigricans. Abundance of these fishes in middle and upper intertidal pools was higher when low tides occurred at night or in the early morning (4.4-9.7 fish per pool) than in the afternoon (1.3-3.4 fish per pool). Mean fish size was also higher during nighttime low tides than daytime low tides. Tidepools higher in the intertidal zone generally displayed greater differences in fish abundance between early morning and afternoon low tides than lower pools. In addition, these upper tidepools reached higher temperatures during afternoon low tides (up to $30 \mathrm{C}$ ) than lower tidepools, often exceeding or nearing the preferred and lethal maximum temperatures reported for the two study species. Diel vertical habitat shifts by middle and upper tidepool fishes indicate that their partitioning of rocky intertidal habitat occurs on short-term temporal as well as spatial scales.
\end{abstract}

$\mathrm{V}^{\mathrm{n}}$ ERTICAL gradients in variables such as emergence time and wave exposure result in vertical zonation of many rocky intertidal species (Connell, 1961a,b; Dayton, 1971). This physical variation, combined with terrestrial and subtidal biotic pressures, leads to microhabitatspecific risks and benefits that are usually inescapable for sessile animals and algae. However, motile organisms may shift their vertical position in response to variable environmental conditions, allowing them to take advantage of zones that are habitable only during certain tidal, diel, lunar, or seasonal periods or that exclude competitors or predators. Motility also enables an organism to accommodate ontogenetic differences in risks and resource requirements by permitting different size or age classes to select different parts of the habitat.

Several studies describe low-tide vertical zonation patterns among fishes (see Yoshiyama, 1981; Gibson, 1982; Zander et al., 1999) and relate these to temperature (Nakamura, 1976b), but combined effects of diel and tidal cycles on shifts in zonation patterns within species have not been examined in the field. The interaction between time of day and time of low tide leads to a complicated pattern of variation in tidepool emergence and physico-chemical characteristics, especially temperature (Lennon, 1995). Temperature may be the most important determinant of an intertidal organism's vertical distribution (Jensen and Muller-Parker, 1994) and affects height distribution of a cottid, Oligocottus snyderi, in the laboratory (Nakamura, 1976a). Diel shifts in low tide timing may also limit or facilitate predation by terrestrial, aerial, and subtidal aquatic predators. For example, an intertidal organism preyed upon by a diurnally foraging predator might remain in a refuge during daytime low tides but might be able to inhabit a wide area during nighttime low tides.

My objective was to evaluate the influence of daily timing of low tides on abundance and size structure of fishes in southern California tidepools. Clinocottus analis, the woolly sculpin (Cottidae), is a permanent tidepool resident and the most abundant fish in those habitats (Davis, 2000). Girella nigricans, the opaleye (Girellidae), is a nursery resident, moving after $1-2$ years of its juvenile phase to the subtidal zone where it spends its adult life (Norris, 1963; Stevens et al., 1989). Both of these species demonstrate site fidelity and homing ability, with individuals repeatedly occupying the same pool or set of pools during consecutive low tides and returning to a home range when displaced (Williams, 1957; Richkus, 1978; Valle, 1989).

I tested the following null hypotheses: (1) the abundance of fish in middle and upper intertidal pools at low tide is similar when low tides occur nocturnally versus diurnally; (2) the size of fish occupying pools is independent of the time of low tide; and (3) diel variation in tidepool fish abundance with time of day is not correlated with factors that affect thermal and chemical stability, such as pool intertidal height. Relationships between fish abundance or size and thermal stability were examined as mechanisms leading to variation in diel habitat use.

\section{Materials and Methods}

I tested the above hypotheses at three sites in San Diego, California: False Point; Ocean Beach; and Dike Rock at the Scripps Coastal Reserve (Fig. 1). Clinocottus analis and G. nigricans 


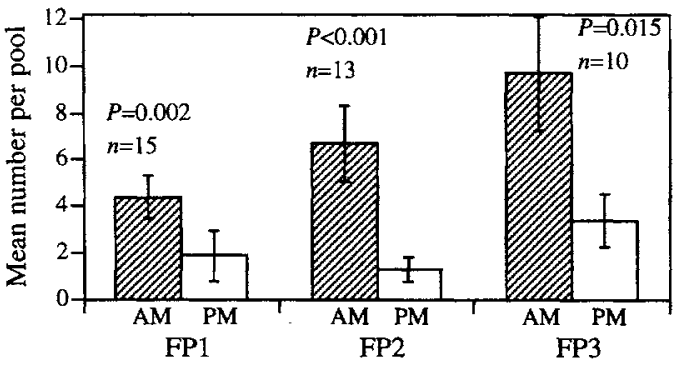

A Total Fish

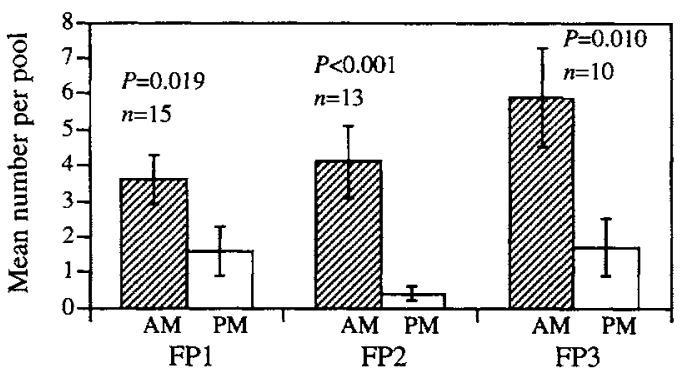

B Clinocottus analis

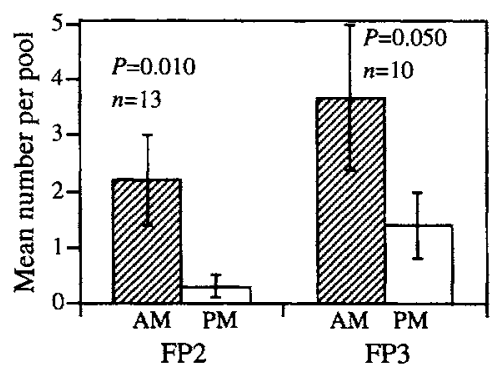

C Girella nigricans

Fig. 1. Number of total fish, Clinocottus analis, and Girella nigricans in middle and upper intertidal pools when low tide was in early morning (AM) versus afternoon (PM). Results of paired ttests are presented for three comparisons made at False Point (FP1, FP2, and FP3). Number of tidepools censused $(n)$ and $P$ values $(P)$ are listed.

were the two most abundant intertidal fishes at these sites during the spring and summer, found up to $100 \mathrm{~cm}$ above mean lower low water (MLLW). Gobiesox rhessodon (Gobiesocidae) was also common but only below $30 \mathrm{~cm}$ MLLW. Hypsoblennius gilberti (Blennidae), Gibbonsia elegans (Clinidae), and Paraclinus integripinnis (Labrisomidae) also contributed to total fish abundance in the lower intertidal zone. The tidal regime along the San Diego coast is mixed semidiurnal, with two unequal low tides per day.

Temperature variation in tidepoals.-Temperatures were measured in 17 pools at False Point on 2 May $1997(1315-1430 \mathrm{~h}), 16$ pools at Ocean
Beach on 3 May 1997 (1240-1420 h), and 21 pools at Ocean Beach on 4 May 1997 (1430 $1600 \mathrm{~h}$ ). Temperature was measured to the nearest $0.1 \mathrm{C}$ using a $\mathrm{YSI}^{\circ} 30$ portable conductivity, salinity, and temperature meter in tidepools at False Point and Ocean Beach. Bottom measurements were taken at the deepest point in the tidepool, where most fishes reside, and surface measurements were taken at the point directly above the deepest area. Regression analysis was used to test the relationship between pool temperature and pool intertidal height. Tidepool intertidal height was measured in a concurrent study (Davis, 2000).

Because temperature in tidepools varies spatially and temporally, temperature in the Dike Rock tidepool was approximated by using average hourly air temperature for the sampling periods 19 July to 4 August and 8 September to 19 September. Tidepools reach maximum temperatures generally at the same time as air temperatures, rarely lagging more than 1 or $2 \mathrm{~h}$ (Morris and Taylor, 1983). Air temperatures were obtained from sensors located on the Scripps Institution of Oceanography Pier $500 \mathrm{~m}$ south of Dike Rock (http://cdip.ucsd.edu/wc/ scripps.html). Duration of tidepool exposure, light conditions during exposure, and time of exposure were determined for the tidepool at Dike Rock using Harbor Master ${ }^{\text {(ind }}$ software.

Distribution of fishes at low tide.-During spring and summer 1997 and spring 1998, I censused fish abundance and size in 10-15 tidepools during paired morning $(0500-0800 \mathrm{~h})$ and midday to afternoon (1100-1600 h) low tides within a 10-day period at False Point and Ocean Beach (Table 1). I collected all fish in each tidepool after water was siphoned or bailed out of the pools and rocks were removed to facilitate detection of fishes. Fishes were removed, measured [total length (TL) in $\mathrm{mm}$ ], identified to species, and returned after restoring rocks and water to the pools.

During the study, six paired comparisons were made of early morning and afternoon low tide censuses from False Point and Ocean Beach (Table 1). The first, second, and third False Point comparisons (FP1, FP2, and FP3) were based on middle and upper intertidal tidepools ranging from $33.5-70.1 \mathrm{~cm}$ above MLLW. Pools at these intertidal height levels are isolated from the subtidal zone for a total of about $22-41 \%$, or about $150-280 \mathrm{~h}$, of a lunar month. To test the effect of intertidal height on diel patterns of tidepool fish abundance, I made three additional comparisons including pools lower in the intertidal zone: False Point 4 (FP4), 
Table 1. Sampling Dates, Times, and Mean Tidal Heights at False Point (FP) and Ocean Beach (OB), San Diego, California.

\begin{tabular}{|c|c|c|c|c|c|c|}
\hline \multirow[b]{2}{*}{ Dataset } & \multirow{2}{*}{$\begin{array}{l}\text { No. of } \\
\text { pools }\end{array}$} & \multirow{2}{*}{$\begin{array}{l}\text { Mean } \\
\text { height } \\
(\mathrm{cm})\end{array}$} & \multicolumn{2}{|c|}{ Early morning low tides } & \multicolumn{2}{|c|}{ Afternoon low tides } \\
\hline & & & $\operatorname{Date}(\mathbf{s})$ & Time(s) & Date(s) & Time(s) \\
\hline FP1 & 15 & 48.8 & 26-28 APR 1997 & $0631-0836$ & 1-2 MAY 1997 & $1159-1249$ \\
\hline FP2 & 13 & 51.8 & 10 JUN 1997 & 0747 & 31 MAY 1997 & 1212 \\
\hline FP3 & 10 & 54.9 & 21 JUL 1997 & 0443 & 20 JUL 1997 & 1520 \\
\hline FP4 & 12 & 39.6 & 27-30 APR 1998 & $0446-0727$ & 3-5 MAY 1998 & $1057-1241$ \\
\hline OB1 & 11 & 30.5 & 10 MAY 1997 & 0648 & 3 MAY 1997 & 1334 \\
\hline OB2 & 13 & 27.4 & 29 APR 1998 & 0636 & 23 APR 1998 & 1354 \\
\hline
\end{tabular}

which included pools from $3.0-70.1 \mathrm{~cm}$ above MLLW, Ocean Beach 1 (OB1), which included pools from $0.0-76.2 \mathrm{~cm}$ above MLLW, and Ocean Beach 2 (OB2), which included pools from -6.1 below to $67.1 \mathrm{~cm}$ above MLLW. The range of isolation times of tidepools in FP4, $\mathrm{OB} 1$, and $\mathrm{OB} 2$ was about $7-41 \%$ of a lunar month.

1 log-transformed total number of fish, number of $C$. analis, and number of $G$. nigricans per pool for statistical analysis. Morning low tide values (abundance and size) were compared with afternoon low tide values using paired $t$-tests. Mean size of $C$. analis and $G$. nigricans were computed for each pool at False Point for FP2, FP3, and FP4. Because of the relatively low abundance of $G$. nigricans at Ocean Beach during early May 1997, comparisons were only made for $C$. analis. Paired $t$-tests were used to compare average fish size per pool during morning and afternoon low tides.

Temporal scale of variation in low tide distribution.I tested hypotheses that fish abundance and fish size are greatest during early morning tides and are negatively correlated with temperature for $G$. nigricans in the largest permanent tidepool at Dike Rock. The pool, located at $51.8 \mathrm{~cm}$ MLLW, measures approximately $5 \mathrm{~m}$ by $1.5 \mathrm{~m}$ and is $40 \mathrm{~cm}$ deep at the deepest point, depending on shifting sand. On 22 occasions during each tide low enough to expose the pool from 19 July to 4 August 1997, a 40-cm minnow trap with 2-mm mesh and openings of $2.8 \mathrm{~cm}$ was deployed for $60 \mathrm{~min}$. During each deployment, the trap was baited with canned cat food and placed in the same location in the same orientation in the tidepool. All opaleye caught in the minnow trap were measured (TL) to the nearest millimeter and released back into the pool. This exercise was repeated from 8 September to 19 September 1997, using two minnow traps. The second trap, with $6 \mathrm{~mm}$ mesh and 4 cm openings, was added to account for increased fish size in September.

Minnow traps were used at Dike Rock but not False Point or Ocean Beach because the Dike Rock pool is much larger than those used the other two sites. Traps did not capture enough individuals for analysis at False Point and Ocean Beach, and the Dike Rock pool was too large to drain. Minnow traps also offered an opportunity for repeated daily sampling over a period of weeks, enabling a more detailed examination of the relationship between fish use of tidepools and timing of low tide.

\section{RESULTS}

Tidepool temperature.-Tidepools reached maximum temperatures between $1350 \mathrm{~h}$ and $1450 \mathrm{~h}$, temperatures up to $10 \mathrm{C}$ higher than surface waters of the subtidal zone immediately offshore. On 2 May at False Point, for example, pools reached values of 24-30 C, 3-9 C warmer than subtidal surface waters $(21 \mathrm{C})$. The magnitude of temperature difference between a tidepool and subtidal surface waters depended on the characteristics of the pool, especially intertidal height. Afternoon temperatures of tidepool bottom water were positively correlated with intertidal height $\left(r^{2}=0.13, P=0.016\right.$ at False Point on 2 May; $r^{2}=0.221, P=0.050$ at Ocean Beach on 3 May; $r^{2}=0.214, P=0.046$ at Ocean Beach on 4 May).

Temporal changes in high intertidal fish abundance.-Abundance of fishes in middle and upper intertidal pools depended on the time of day the pools were isolated. During the first three False Point study periods, middle and upper intertidal tidepools isolated by afternoon low tides had significantly fewer fishes (total number of individuals) and fewer $C$. analis individuals than the same set of pools isolated by morning low tides (Fig. 1). Girella nigricans abundance showed the same pattern during the 

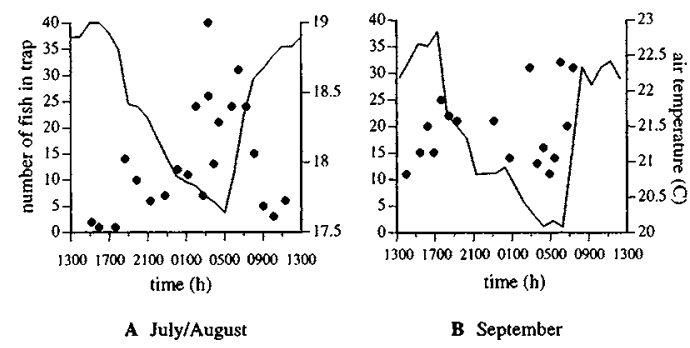

Fig. 2. Number of Girella nigricans trapped at Dike Rock relative to the time of day of low tide in (A) late July to early August, and (B) September. Mean hourly air temperature at Dike Rock for the sampling periods is also plotted. Fish abundance was correlated with mean air temperature at the time of pool isolation in July/August ( $\left.n=21, r^{2}=0.45, P<0.001\right)$ but not in September $\left(n=17, r^{2}=0.01, P=0.69\right)$.

second and third False Point periods (FP2 and FP3). Abundance of $G$. nigricans was not analyzed for the first period (FP1) because the fish was present in only two pools in the early morning and no pools in the afternoon.

Abundance of $G$. nigricans at Dike Rock in July and August 1997 displayed a pattern similar to that described for $C$. analis. Abundance was greater during low tides that isolated the pool in hours of darkness $(2000-0600 \mathrm{~h})$ than in daylight hours $\left(t_{8,12}=4.1, P<0.001\right)$. This difference was not observed in September $1997\left(t_{10,5}\right.$ $=0.1, P=0.954$; Fig. 2). Average air temperature was lowest just before dawn and greatest from 1400 to $1500 \mathrm{~h}$ during both the July/August and September sampling periods. Girella nigricans abundance in the Dike Rock tidepool was significantly correlated with average air temperature during the July/August sampling period at the time of pool isolation $\left(n=21, r^{2}=\right.$ $0.45, P<0.001)$ and the time at low tide $(n=$ $\left.21, r^{2}=0.49, P<0.001\right)$. These abundance relationships did not persist in September (temperature at isolation: $n=17, \mathrm{r}^{2}=0.01, P=$ 0.69 ; temperature at low tide: $n=17, r^{2}<0.01$, $P=0.90)$.

Spatial patterns of abundance-high and low intertidal pools.-The effect of low tide timing on fish abundance was related to intertidal height in two of the three False Point/Ocean Beach study periods that included low intertidal pools. In those two periods (FP4 and OB1), the log-transformed difference in fish abundance between morning and afternoon was positively correlated with intertidal height $\left(n=12, r^{2}=0.58, P\right.$ $=0.004$ for FP4; $n=11, r^{2}=0.37, P=0.026$ for $\mathrm{OB} 1)$. The relationship was not significant in OB2 $\left(n=13, r^{2}=0.03, P=0.611\right)$. As in
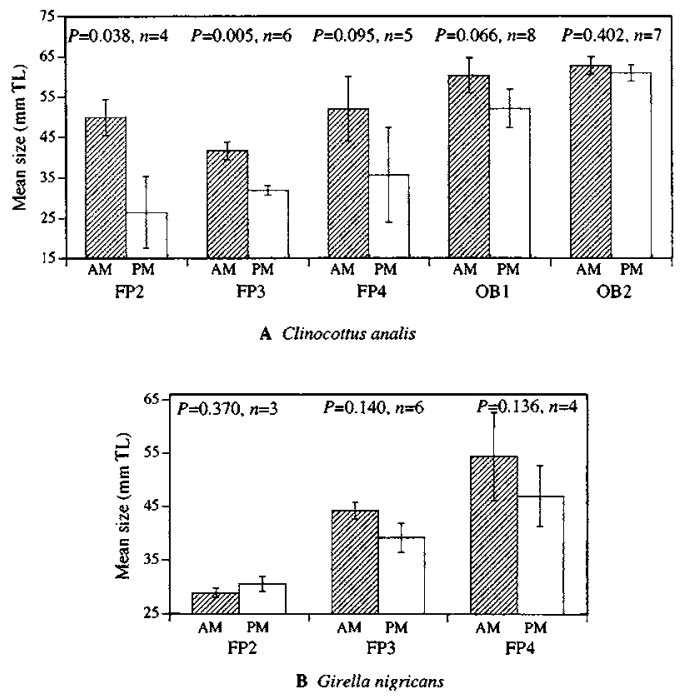

Fig. 3. Mean size ( $\pm 1 \mathrm{SE}$ ) of Clinocottus analis and Girella nigricans collected in all tidepools at low tide in early morning (AM) versus afternoon (PM). Five comparisons between morning and afternoon censuses were made, three at False Point (FP2, FP3, FP4) and two at Ocean Beach (OB1, OB2), San Diego, using paired $t$-tests. $P$-values $(P)$ and the number of tidepools containing fish in both the morning and afternoon $(n)$ are given.

FP1-3, the six middle and upper pools of FP4 had significantly lower numbers of total fish $\left(t_{5}\right.$ $=2.9, P=0.035)$ and $C$. analis $\left(t_{5}=4.5, P=\right.$ $0.007)$ during the afternoon low tides than during the early morning low tides. In contrast, the six lowest intertidal pools did not have different numbers of total fish $\left(t_{5}=1.8, P=0.138\right)$ or C. analis $\left(t_{5}=0.3, P=0.801\right)$ when the low tide occurred in the afternoon compared with the morning. Girella nigricans was not abundant enough to be included in this analysis.

Temporal patterns in fish size.-Fishes of different sizes responded differently to changes in timing of low tide. In middle and upper intertidal pools (FP2 and FP3), mean size of C. analis per pool was greater when low tides occurred during the early morning than the afternoon (Fig. 3). Girella nigricans size was not different between morning and afternoon low tides, but low numbers of $G$. nigricans found per pool during the afternoon tides $(0.3,1.4$, and 2.2 fish per pool for FP2, FP3, and FP4, respectively) reduced the power of statistical tests. Girella nigricans was not found in enough pools for comparison at Ocean Beach.

Girella nigricans collected at Dike Rock ranged from $25-67 \mathrm{~mm}$ total length during July/August and from 31-89 mm during September. Mean 


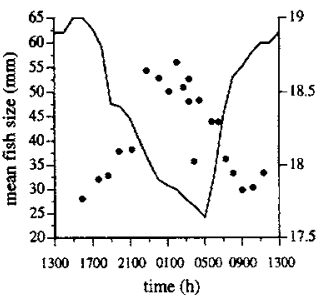

A July/August

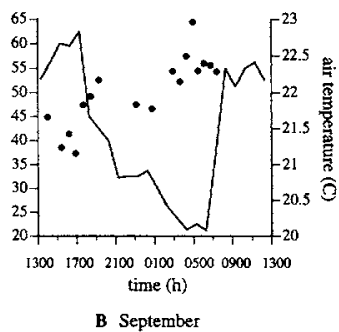

B September
Fig. 4. Mean size of Girella nigricans trapped at Dike Rock in (A) late July to early August, and (B) September relative to the time of day of low tide. Mean hourly air temperature at Dike Rock for the sampling periods is also plotted. Mean fish size was correlated with mean air temperature at the time of pool isolation in July/August $\left(n=21, r^{2}=0.060, P\right.$ $<0.001)$ and September $\left(n=17, r^{2}=0.36, P=\right.$ 0.011 ).

size of trapped $G$. nigricans was significantly greater when the study area was isolated at night than during daylight hours in both July/August and September $\left(t_{8,12}=4.9, P<0.001\right.$ and $t_{10,5}$ $=3.1, P=0.008$, respectively, Fig. 4). To identify differences in response by different size classes of fish, abundance patterns were analyzed separately for two size classes: $\geq 45 \mathrm{~mm} \mathrm{TL}$ ("large") and $<45 \mathrm{~mm}$ TL ("small"). During both sampling periods, the mean number of large individuals trapped when the pool was isolated at night was greater than the mean number trapped after daylight isolations (night: 10.3 \pm 2.0 , day: $0.4 \pm 0.2, t_{8,12}=3.51, P=0.002$ for July/August, and night: $12.5 \pm 1.1$, day: $6.5 \pm$ 2.2, $t_{10,5}=2.11, P=0.052$ for September). Results for small fish were not consistent between sampling periods. In July/August, mean numbers of small fish trapped after daylight and nighttime isolations were not different $\left(t_{8,12}=\right.$ $1.42, P=0.169$ ). In September, the number of small fish trapped after daylight isolations was greater than the number trapped after nighttime isolations (day: $11.3 \pm 1.8$, night: $6.9 \pm 0.8$, $t_{10,5}=2.36, P=0.032$ ). The opposite diel pattern of small and large fish in September caused the lack of relationship, described above, between total abundance and time of day.

Fish size at Dike Rock was negatively correlated with average air temperature in both July/ August and September. Correlations between mean fish size and temperature both at low tide (July/August: $n=21, r^{2}=0.19, P=0.051$; September: $n=17, r^{2}=0.43, P=0.004$ ) and at the time of pool isolation (July/August: $n=21$, $r^{2}=0.60, P<0.001$; September: $n=17, r^{2}=$ $0.36, P=0.011$ ) were significant (Fig. 4).

\section{Discussion}

In the present study, vertical distribution of middle and upper intertidal fishes shifted depending on timing of low tide and life stage. Clinocottus analis and G. nigricans were more likely to occupy middle and upper intertidal pools during nighttime low tides and less likely to occupy these areas during daytime low tides. The strength of the diel influence on tidepool occupation depended on intertidal height. Lowest pools were occupied by more fishes when low tide was in the afternoon than the early morning. These results suggest that, although pools at different heights are available during all parts of the day, some are less habitable at certain times.

During low tide, a motile tidepool organism can inhabit a high intertidal tidepool with a lengthy isolation time, a lower intertidal pool with shorter isolation time, or areas contiguous with the subtidal zone. Isolation offers protection from subtidal competitors and predators, such as the cottid Scorpaenichthys marmoratus (Yoshiyama, 1981; Wyttenbach and Senn, 1993). However, isolation exposes fishes to the potential of heat-related physiological stress (Zander et al., 1999), subjects fishes to predation by intertidal predators such as birds (Yoshiyama, 1981; Pierce and Pierson, 1990; Horn et al., 1999), and restricts foraging area (Wyttenbach and Senn, 1993; Zander et al., 1999). Immersion offers protection from intertidal predators and physiological stress and access to forage areas outside the tidepool, but may expose intertidal fishes to subtidal competitors and predators.

The potential for temperature-related physiological stress may play a role in diel vertical habitat shifts by fishes. In the laboratory, the cottid Oligocottus snyderi occupied "lower tidepools" (basins that were isolated by an experimental tide for shorter periods of time) during a high temperature regime $(23.5 \mathrm{C})$ than a cold regime (11.5-13.5 C; Nakamura, 1976a). This result and those of the present study suggest that fishes occupy upper intertidal pools during cool hours and remain in lower pools during periods when temperature becomes stressful. In the present study, May afternoon bottom temperatures of middle and upper intertidal pools often exceeded the lethal maximum temperature of C. analis (26-27 C; Graham, 1970) and the preferred temperature $(25.6-26.5 \mathrm{C})$ of unacclimated $G$. nigricans collected from field sites of differing thermal regimes (Douderoff, 1938; Norris, 1963). The highest tidepool bottom temperatures measured in the present study 
were only a few degrees less than the upper lethal temperature of 60-92 $\mathrm{mm}$ SL $G$. nigricans (31-33 C; Douderoff, 1942), and temperature of the Dike Rock study pool can often reach 35 $C$ in the summer (Norris, 1963; unpubl.). High temperatures may be physiologically disadvantageous to $G$. nigricans; individuals in the laboratory grew almost twice as fast at $17.6 \mathrm{C}$ than at $27.5 \mathrm{C}$ (Norris, 1963). Other physical and chemical properties that change in tidepools on a diel cycle may also be important physiologically, such as the decrease of oxygen solubility in seawater during the day, increase in $\mathrm{pH}$, and increase in salinity (Morris and Taylor, 1983; Horn et al., 1999).

The risk of intertidal predation may also change on a diel cycle. Diurnal nonaquatic predators, especially birds, may affect the spatial distribution of intertidal fishes (Yoshiyama, 1981; Pierce and Pierson, 1990). Several bird species, including herons (Ardea herodias), egrets (Leucophoyx thula), and willets (Catoptrophorus semipalmatus), have been observed to feed during low tide on tidepool cottids and other fishes along the coast from southern California to Washington (Yoshiyama, 1981; Pierce and Pierson, 1990; pers. obs). Intertidal fish may abandon high intertidal areas before daytime low tides to limit exposure to these predators.

Lower average fish size during daytime than nighttime low tides indicates that time spent in tidepools versus subtidal conditions is a function of ontogeny as well as time of day. In laboratory experiments, temperature preference of G. nigricans was stage- and size-specific (Norris, 1963). Newly settled fish (usually $<30 \mathrm{~mm} \mathrm{SL}$ ) preferred temperatures of $28 \mathrm{C}$, whereas older fish (30-80 mm SL) chose temperatures of 26 C (Norris, 1963). Optimum temperature for growth decreases with size in many fish species (Brett, 1979; Pedersen and Jobling, 1989), and although this trend has not been demonstrated for the two study species, Norris (1963) hypothesized that temperature selection in young $G$. nigricans serves to guide them to areas where growth rate is greatest. In the present study, mean fish size in the Dike Rock pool was inversely related to temperature, suggesting that ontogenetic differences in physiology play a role in vertical habitat selection.

Similarity in diel patterns of tidepool occupation between $C$. analis and $G$. nigricans, two phylogenetically, ecologically, and behaviorally different species (Graham, 1970; Norris, 1963), suggests that upper-intertidal fishes share a general strategy. The hypotheses that explain the pattern described above (physiological forces and predation avoidance) are not mutually exclusive. Both may lead to increased nighttime densities of larger fish in high pools, and smaller individuals may avoid this microhabitat at night because of intraspecific competition with larger fish. Intraspecific aggression has been observed in C. analis, especially in larger fish (Yoshiyama, 1981), in other tidepool cottids (Pfister, 1995) and in G. nigricans in the laboratory (pers. obs.). Replication of this study at other latitudes within the ranges of $C$. analis and $G$. nigricans would determine whether this strategy is shared by populations in both cooler and warmer areas. If shifts occur to relieve thermal stress, more pronounced shifts might be expected south of San Diego and reduced shifts expected to the north.

The avoidance of the middle and upper intertidal zone by fishes during daytime low tides, as well as differential habitat use patterns by different size classes, has potential to cause sampling bias in rocky intertidal systems. Often, as is the case in California, lowest low tides occur in the afternoon during one season (winter, in California) and in the early morning in the opposite season (summer, in California). Seasonal declines observed in fish populations when afternoon spring tides prevail could simply reflect a redistribution of fish to lower pools that are more difficult to sample. Results also indicate that fishes select habitat in response to factors that change on daily and tidal cycles and that fishes may have to assess both diurnal and tidal rhythms at the same time. Homing studies of rocky intertidal fishes indicate spatial complexity in tidepool use by fishes (Williams, 1957; Valle, 1989; Yoshiyama et al., 1992). The discovery of diel patterns in tidepool use implies temporal complexity as well.

\section{ACKNOWLEDGMENTS}

Thanks to L. Levin, R. Gibson, D. Checkley, P. Dayton, A. Juhl, P. Smith, T. Price, and C. Wynant for reading the manuscript and offering many helpful comments and ideas. Thanks to my late-night helpers at Dike Rock and to the Scripps Coastal Reserve for permitting me to use Dike Rock as a study site. Funding was provided by the J. M. Hepps and National Defense Science and Engineering Graduate Fellowships, the Mildred Mathias Foundation, the Sigma Xi Foundation, Sigma Delta Epsilon Graduate Women in Science, and the PADI Foundation.

\section{LITERATURE GITED}

BRETT, J. R. 1979. Environmental factors and growth, p.599-675. In: Fish physiology 8: biogenics and 
growth. W. S. Hoar, D. J. Randall, and J. R. Brett (eds.). Academic Press, New York.

Connel., J. H. 196la. The influence of interspecific competition and other factors on the distribution of the barnacle Balanus balanoides. Ecol. Monogr. 13:61-104.

- $1961 \mathrm{~b}$. The influence of interspecific competition and other factors on the distribution of the barnacle Chthamalus stellatus. Ecology 42:710-723.

DAvis, J. L. D. 2000. Spatial and seasonal patterns of habitat partitioning in a guild of southern California tidepools fishes. Mar. Ecol. Progr. Ser. 196:253268.

DAYTON, P. K. 1971. Competition, disturbance, and community organization: the provision of space in a rocky intertidal community. Ecol. Monogr. 41: 351-389.

DouderofF, P. 1938. Reactions of marine fishes to temperature gradients. Biol. Bull. 75:494-509.

- 1942. The resistance and acclimatization of marine fishes to temperature changes I. Experiments with Girella nigricans (Ayres). Ibid. 83:219244.

GiBsON, R. N. 1982. Recent studies on the biology of intertidal fishes. Oceanogr. Mar. Biol. Annu Rev. 20: 363-414.

GRAHAM, J. B. 1970. Temperature sensitivity of two species of intertidal fish. Copeia 1970:49-56.

Horn, M. H., K. L. M. Martin, and M. A. ChotKowSKI. 1999. Introduction, p.1-6. In: Intertidal fishes. M. H. Horn, K. L. M. Martin, and M. A. Chotkowski. (eds.). Academic Press, San Diego, CA.

JENSEN, S. L., AND G. Muller-PARKER. 1994. Inorganic nutrient fluxes in anemone-dominated tide pools. Pac. Sci. 48:32-43.

LENNON, J.-F. 1995. Is the variation of the temperature in an intertidal pool diel or tidal? A paradigm for studying biological rhythms in the tidal zone. Chronobiol. Int. 12:229-236.

Morris, S., AND A. C. TAYLOR. 1983. Diurnal and seasonal variation in physico-chemical conditions within intertidal rock pools. Est. Coast. Shelf Sci. 17: 339-355.

NAKAMURA, R. 1976a. Experimental assessment of factors influencing microhabitat selection by the two tidepool fishes Oligocotius maculosus and O. snyderi. Mar. Biol. 37:97-104.

1976b. Temperature and the vertical distribution of two tidepool fishes. Copeia 1976:143-152.

NorRIs, K. S. 1963. The functions of temperature in the ecology of the percoid fish Girella nigricans (Ayres). Ecol. Monogr. 33:23-61.
Pedersen, T., AND M. Jobling. 1989. Growth rates of large, sexually mature cod, Gadus morhua, in relation to condition and temperature during an annual cycle. Aquaculture 81:161-188.

PfISTER, C. A. 1995. Estimating competition coefficients from census data: a test with field manipulations of tidepool fishes. Am. Nat. 146:271-291.

Pierce, B. E., AND K. B. Pierson. 1990. Growth and reproduction of the tidepool sculpin Oligocottus maculosus. Jpn. J. Ichthyol. 36:410-417.

RichkUs, W. A. 1978. a quantitative study of the inter tidepool movement of the woolly sculpin, Clinocottus analis. Mar. Biol. 49:277-284.

Stevens, E. G., W. WAtSON, AND H. G. Moser. 1989. Development and distribution of larvae and pelagic juveniles of three kyphosid fishes (Girella nigricans, Medialuna californiensis, and Hermosilla azurea) off California and Baja California. Fish. Bull. 87:745768.

VALLE, C. F. 1989. The homing behavior and intertidal movements of the opaleye, Girella nigricans. Unpubl. master's thesis, California State Univ., Long Beach.

Willıams, G. C. 1957. Homing behavior of California rocky shore fishes. Univ. Calif. Publ. Zool. 59:249284.

WYTTENBACH, A. AND D. G. SENN. 1993. Intertidal habitat: does the shore level affect the nutritional condition of the shanny (Lipophrys pholis, Teleostei, Blenniidae)? Experientia 49:725-728.

YoshIYAMA, R. M. 1981. Distribution and abundance patterns of rocky intertidal fishes in central California. Environ. Biol. Fish. 6:315-332.

一, K. B. Gaylord, M. T. Philippart, T. R. MoOre, J. R. Jordan, C. C. CoOn, L. L. Schalk, C. J. VALPEY, AND I TOSQUES. 1992. Homing behavior and site fidelity in intertidal sculpins (Pisces: Cottidae). J. Exp. Mar. Biol. Ecol. 160:115-130.

ZANDER, C. D., J. Nieder, and K. MARTin. 1999. Vertical Distribution Patterns, p. 26-53. In: Intertidal fishes. M. H. Horn, K. L. M. Martin, and M. A. Chotkowski (eds.). Academic Press, New York.

SCRIPPS INSTITUTION OF OCEANOGRAPHY, 9500 Gilman Drive-0208, San Diego, California 92093-0208. Present ADdREsS: SMITHSONIAN ENVIRONMENTAL RESEARCH CENTER, P.O. BOX 28, 647 CONTEES WHARF ROAD, EDGEWATER, MARYLAND 21037. E-mail: janalddavis@yahoo.com. Submitted: 16 Aug. 1999. Accepted: 8 Dec. 2000. Section editor: W. L. Montgomery. 